\title{
Orson de Beauvais. Chanson de geste du XII siècle, publiée par Jean-Pierre Martin
}

\section{G. Matteo Roccati}

\section{Q OpenEdition}

12 Journals

\section{Édition électronique}

URL : http://journals.openedition.org/studifrancesi/35648

DOI : $10.4000 /$ studifrancesi.35648

ISSN : 2421-5856

Éditeur

Rosenberg \& Sellier

\section{Édition imprimée}

Date de publication : 1 juillet 2005

Pagination : 127

ISSN : 0039-2944

\section{Référence électronique}

G. Matteo Roccati, "Orson de Beauvais. Chanson de geste du XI/e siècle, publiée par Jean-Pierre Martin », Studi Francesi [En ligne], 145 (XLIX | I) | 2005, mis en ligne le 30 novembre 2015, consulté le 18 avril 2021. URL : http://journals.openedition.org/studifrancesi/35648; DOI : https://doi.org/10.4000/ studifrancesi.35648

Ce document a été généré automatiquement le 18 avril 2021.

\section{(c)}

Studi Francesi è distribuita con Licenza Creative Commons Attribuzione - Non commerciale - Non opere derivate 4.0 Internazionale. 


\title{
Orson de Beauvais. Chanson de geste du $X I I^{\mathrm{e}}$ siècle, publiée par Jean-Pierre Martin
}

\author{
G. Matteo Roccati
}

\section{RÉFÉRENCE}

Orson de Beauvais. Chanson de geste du XII siècle, publiée par Jean-Pierre MARTIN, Paris, Honoré Champion éditeur («Les classiques français du Moyen Age», 140), 2002, pp. 262.

1 L'édition remplace la seule existante à présent (G. Paris, 1899) de ce texte conservé dans un manuscrit unique (paris, BnF, n.a.f. 16600). L'introduction (pp. 7-65) justifie le travail, donne un résumé du contenu du texte ainsi que l'étude de la langue et de la versification (copiste et auteur). Cela aboutit à proposer comme date de composition les années entre 1180 et 1200 , le texte que nous avons étant «un remaniement ou une réécriture partielle du texte» (p. 39) à situer aux alentours de 1225.

2 Suit l'étude littéraire, claire et pertinente. Elle met bien en évidence les parentés avec d'autres chansons - notamment celles dont l'auteur s'est inspiré, la chanson étant «selon toute apparence une adaptation picarde» (p. 40) de Beuve de Hantone -, l'organisation du contenu, la caractérisation des personnages, les thématiques structurant le récit, romanesque tout en restant fidèle à la tradition épique - celle de l'inceste en particulier, qui donne lieu à un traitement élaboré -, enfin l'art épique. Des «Éléments de bibliographie» et les principes d'édition (conservative) terminent l'introduction.

3 Le texte (3741 alexandrins, en laisses rimées et assonancées) est suivi des leçons rejetées (pp. 183-185), des notes (pp. 186-208), de l'index des noms propres (pp. 209-225) et du glossaire (pp. 226-259). 